\title{
Virgil's Aeneid
}

Hic labor ille domus et inextricabilis error.

Here is the toil of that house, and the inextricable wandering.

Virgil, Aeneid 6.27

HE Aeneid, one of the most influential works of western
literature, is the earliest major example of truly labyrin-
thine literature: it includes explicit images of the maze and references to its myth, employs a labyrinthine narrative structure, and embodies themes associated with the idea of the labyrinth (as defined in previous chapters). ${ }^{1}$ Although the importance of the labyrinth in Books 5 and 6 has not gone unnoticed, ${ }^{2}$ the full extent and significance of

1. In this chapter I continue to follow the LCL Latin text of the Aeneid, trans. Fairclough, but translations are my own unless otherwise noted.

2. See Robert W. Cruttwell, Virgil's Mind at Work: An Analysis of the Symbolism of the Aeneid (1947; rpt. New York: Cooper Square Publishers, 1969), chap. 7, for a fairly comprehensive but bizarre examination of labyrinths in the poem; Mario di Cesare, The Altar and the City: A Reading of Virgil's Aeneid (New York: Columbia University Press, 1974), pp. 83-84 and chap. 4; William Fitzgerald, "Aeneas, Daedalus, and the Labyrinth," Arethusa, 17 (1984), $5^{1-65}$ (the best study to appear to date); W. F. Jackson Knight, "Vergil and the Maze," CR, 43 (1929), 212-213, and, following Cruttwell's work, Roman Vergil (London: Faber \& Faber, 1944), pp. 167-169, and Vergil: Epic and Anthropology (London: Allen \& Unwin, 1967), chaps. 8-9; Michael C. Putnam, The Poetry of the Aeneid (1965; rpt. Ithaca: Cornell University Press, 1989), pp. 85-88; and Clark, Catabasis, chap. 6.

Focusing more narrowly on Daedalus and the Cumaean gates in Book 6: William S. Anderson, The Art of the Aeneid (Englewood Cliffs, N.J.: Prentice-Hall, 1969), pp. 55-62; A. J. Boyle, "The Meaning of the Aeneid: A Critical Inquiry, Part II: Homo Immemor: Book VI and Its Thematic Ramifications," Ramus, 1 (1972), 113-151, esp. 113-119; Page duBois, History, Rhetorical Description, and the Epic (Cambridge: D. S. Brewer-Biblo, 1982), pp. 35-41; D. E. Eichholz, "Symbol and Contrast in the Aeneid," Greece and Rome, ser. 2, 15 (1968), 105-112; P. J. Enk, "De labyrinthii imagine in foribus templi cumani insculpta," Mnemosyne, ser. 4, 2 (1958), 322-330; Cynthia King, "Dolor in the Aeneid: Unspeakable and Unshowable," Classical Outlook, 56 (1979), 106; Margaret de G. Verrall, "Two Instances of Symbolism in the Sixth Aeneid," CR, 24 (1910), 43-46; Brooks Otis, Virgil: A Study in Civilized Poetry (Oxford: Clarendon Press, 1964), pp. 284-285; Viktor Pöschl, The Art of Vergil, trans. Gerda Seligson (Ann Arbor: University of Michigan Press, 1962), pp. 149- 
labyrinthine imagery and ideas in the Aeneid have not yet been explored. I hope to show that the idea of the labyrinth constitutes a major if sometimes covert thread in the elaborate textus of the Aeneid, providing structural pattern and thematic leitmotif. Three works of complex visual art are described in minute detail in the poem: the doors of the Temple of Juno in Carthage depicting the Trojans' labores (1.46o), the Cumaean gates with their Daedalian memorial of the Cretan myth, and the shield of Aeneas, proclaiming the future of Rome. The centerpiece of this triptych, the first thing Aeneas sees when he lands in his country of destiny, depicts the history of the labyrinth; this fact surely hints at broad potential significance for the image and its myth within the poem. ${ }^{3}$ As we shall see, the labyrinths of Books 5 and 6 , discussed in Chapter 1 , are only part of a network of allusions that gradually shape a vision of Aeneas's life as a laborious errand through a series of mazes. ${ }^{4}$ First I trace the idea of the labyrinth in the poem; then I explore its significance for the work as a whole.

150; Eduard Norden, P. Vergilius Maro Aeneis Buch VI (Stuttgart: B. G. Teubner, 1957), pp. 121-130; Harry C. Rutledge, "Vergil's Daedalus," CJ, 62 (1967), 309-311, and "The Opening of Aeneid 6," CJ, 67 (1972), 110-115; John W. Zarker, "Aeneas and Theseus in Aeneid 6," CJ, 62 (1966), 220-226.

And, discounting the importance of the labyrinth even in Book 6: Robert A. Brooks, "Discolor Aura: Reflections on the Golden Bough," AJP, 74 (1953), 26o-28o, repr. in Steele Commager, Virgil: A Collection of Critical Essays (Englewood Cliffs, N.J.: Prentice-Hall, 1966), pp. 143-163.

3. See duBois, who argues that the ekphraseis in the Aeneid "define massive, significant thresholds that instruct those who pass through them" (p. 29) and represent Aeneas's past, present, and future, which Aeneas understands less and less fully.

4. In what follows, I generally ignore Homeric parallels, cross-relations with other classical literature (including Catullus 64), and the Augustan context. I assume that Virgil knew the traditions preserved for us by Pliny, Plutarch, and others, even though that assumption cannot be verified (but see Enk on Varro and Pliny). I read from a medievalist's perspective, at my disposal the lexicon of labyrinth lore established in preceding chapters. Yet I do not read as a medieval commentator would have done: I have looked at a broad range of published and manuscript commentaries and marginalia, from Servius through the fifteenth century, and have found little to support my interpretation.

However, the vastly popular Histoire ancienne jusqu'à César (early thirteenth century) makes the Daedalian sculptures the focus of its précis of Book 6, and at least three manuscripts of this work select the labyrinth (twice accompanied by the Minotaur) as one of only two or three illustrations of the whole history of Aeneas: for Paris BN fr. 20125 , see plate 19, Appendix, MS. 6, and Monfrin, "Les translations vernaculaires de Virgile au Moyen Age," pp. 189-249; for Paris BN fr. 9682 and Dijon Bibl. Municipale 562, see Buchthal, Miniature Painting in the Latin Kingdom of Jerusalem, pp. 68-87 and Catalogue (also my plate 18). Surprisingly, Jeanne Courcelle omits these illuminations in her discussion of Histoire ancienne manuscripts: Pierre Courcelle, Lecteurs païens et lecteurs chrétiens de l'Énéide, vol. 1 : Les Témoignages littéraires, and vol. 2, by P. Courcelle and Jeanne Courcelle: Les Manuscrits illustrés de l'Éneide du $X^{e}$ au $X V^{e}$ siècle (Paris: Institut de France, 1984). For readers of the Histoire ancienne, then, text and sometimes illuminations would point to the importance of the labyrinth in the Aeneid. As the following chapters show, other medieval readers also noticed and creatively imitated the centrality of the labyrinth.

For a far-ranging discussion of medieval Virgil commentaries, see Christopher Baswell, “'Figures of Olde Werk."” 
The labor and error associated with mazes are repeatedly emphasized in the Aeneid. The poem dwells on labores of various sorts: works of suffering, achievement, and art. The psychological and physical labores of Aeneas, his companions, and his descendents are necessary to build Rome, whose characteristic art will be government $\left(6.85^{1-854}\right)$, bringing order to chaos. Through his labors, Aeneas becomes a second, more complex, version of Theseus, the maze-tamer king who knows how to handle errores, and of Daedalus, inventor, artist, exile, and shaper of chaos. Aeneas's labors also render him kin to Hercules, whose labors are celebrated in Arcadia, whose slaying of the giant Cacus foreshadows Aeneas's destruction of Turnus, and whose successful descent into Hades preceded that of Aeneas (6.392). ${ }^{5}$

If labyrinthine labor ("hic labor ille domus"-6.27) pervades the Aeneid thematically and verbally, so does its labyrinthine twin, error, whether as circuitous wandering or as mental misjudgment. For example, Book 3 is a narrative labyrinth describing Aeneas's errores (1.755) throughout the Mediterranean, wanderings whose goal is a stable domus and whose geographical pattern imitates the meanderings of the maze. After much tracing and retracing of steps in Troy, Aeneas sails first to Aeneadae and then to Delos, originally an errans isle that was eventually fixed in place only to instigate other errors by its ambiguous oracles to wanderers (3.76, 96-101); the labyrinth's characteristic shapeshifting from chaos to order and from stability to instability, a recurrent motif in the poem, is thus reflected in the portrayal of Apollo's birthplace just as the labyrinth itself will figure on his temple at Cumae. At Crete, ancient home of mazes and Trojans alike, the voyagers vainly wish to retrace their steps to Delos (3.143) and find the end of their labors (3.145). Despite divine and human guidance, they wander through blind waves $(3.200,204)$ to the Strophades, where the Harpies give directions but predict obstacles. At Buthrotum, Helenus prophesies a circuitous course (3.376) on pathless tracks (3.383) before Aeneas may find rest after labor (3.393) in Italy, so near in space yet so distant in time. Instead of taking the nearest path, Helenus advises, Aeneas must go the longest way round (3.412-413, 430 ), until finally the Sibyl shows the path and tells what labor to flee and what to follow (3.459-46o). ${ }^{6}$ Although the proper route is clearly defined, the Trojans take the shortest path despite Helenus's warning (3.507); soon they are lost, ignari viae $(3.569)$ - the human condition in

5. On Hercules, see Anderson, pp. 7o-72; Camps, chap. 8; Otis, pp. 334-336; Putnam, p. 134; Kenneth Quinn, Virgil's Aeneid: A Critical Description (Ann Arbor: University of Michigan Press, 1968), p. 123; and Di Cesare, p. 146. Pseudo-Bernard Silvester cites Hercules as an exemplar of the virtuous descent to Hades: J\&J, p. 32, and S\&M, p. $3^{2}$.

6 . The idea of fleeing vs. following, related to the continuous to-ing and fro-ing within a maze as well as to the idea of choosing the right path, is picked up at the end of Anchises' commission to Aeneas in 6.892 . 
this poem's universe-and must retrace their steps (3.686-691), arriving at an illusory end of wandering labors in Drepanum (3.714). After further errores (1.32), they wander off course, driven to Carthage by Juno's storm. Throughout their erratic voyage the Trojans confront typically labyrinthine dangers: circuitous paths that near a goal only to turn away or reveal the goal as false; enforced delay and hesitation among uncertain choices; unreliable guides in the form of ambiguous visions and prophecies, or uncertain helmsmen plagued by darkness; perils represented or announced by monsters as double in form as the Minotaurthe Trojan Horse, wooden animal concealing men; Polydorus, whose vegetable form has human blood; the bird-maiden Harpies; the dogmaiden Scylla. By such methods the text covertly establishes the image of the labyrinth: labor through blind error, ${ }^{7}$ a seemingly endless search for a clear path to the perpetually deferred goal of requies after labor, a preordained domus. If labor is the content of Aeneas's mission, errores define its form: the two concepts are as intimately connected in the poem as in a maze. Success, therefore, demands both the persistent patience of the passive unicursal maze-walker and the active intelligence that can choose the right path in a multicursal maze. 8

While the errores of Book 3 suggest the subjective experience of tracing a labyrinthine path, analogues to the labyrinth as an object and to the monstrum biformis within figure at the start of Book 2. In the proximate causes of Troy's downfall, the Trojan Horse and the serpents that kill Laocoon and his sons, ${ }^{9}$ we may detect a constellation of words and ideas traditionally linked with the labyrinth. Like the Cretan labyrinth defined by Virgil himself in Books 5 and 6 (see Chapter 1), the horse is a monu-

7. The errores are both mental and physical: neither Aeneas's nor Anchises' judgment is always sound, as Anchises himself acknowledges (3.181). Indeed, Aeneas's labores and errores generally involve at least a temptation to mental error.

8. The theme of labyrinthine wanderings is subtly heralded upon Aeneas's arrival in Libya, when he speaks in the words of a maze-walker: he asks that Venus lighten his labor and tell him where he is, for he has wandered in ignorance (1.330-333). She responds by leading him into a metaphorical labyrinth of love by describing the ambages (1.342) of Dido's life; the ambages of the Dido episode will delay Aeneas's own progress. Dido's history also suggests the labyrinth: it involves complexity (ambages), blind impiety, the concealing and then unweaving (retexit) of the blind crime of her house (caecum domus scelus). The collocation of blindness, crime, a house, and weaving connotes a labyrinth. Dido goes on to found her city through deception involving a bull; this magna regina has something in common with the abandoned Pasiphae and Ariadne abandoned.

9. On the imagery and significance of horse and serpents, see Bernard M. W. Knox, "The Serpent and the Flame: The Imagery of the Second Book of the Aeneid," AJP, 71 (1950), 379-400, repr. in Commager, Virgil, pp. 124-142; Boyle, "The Meaning of the Aeneid: A Critical Inquiry. Part I: Empire and the Individual: An Examination of the Aeneid's Major Theme," Ramus, 1 (1972), 63-9o, here, 81-85, and part II, $136 \mathrm{ff}$. (on serpents and the golden bough); Otis, Virgil, pp. 242-250; and Putnam, Poetry of the Aeneid, chap. 1, which also compares Aeneas's wanderings in Troy with his journey through the underworld and Nisus's and Euryalus's quest through the "malignant maze of the obscure wood" (p. 57) - a comparison he does not explore further. 
mental work of art linked with trickery (dolus: $2.15,44-\mathrm{cf} .5 .590,6.29$ ) and built by guileful Greeks (Calchas and Epeos vs. Daedalus). Both creations are intricately woven (textum: $2.16,185$-cf. $5.589,593$ ) and contain error $(2.48,6.27)$. Like the Cretan maze, the horse is dark and cavernous (caecus: 2:19, 5.89, 6.30; caverna, 2.19, 53-implicit in Books 5 and 6). Labyrinth and horse alike contain both danger and crafty Greeks: the Minotaur and the Athenians Daedalus and Theseus in the labyrinth, Ulysses and his companions in the horse. Each involves a hybrid monstrum biformis: the Minotaur is a fierce bull-man, the horse a wooden animal containing armed men. Both are prisons, the labyrinth intentionally and the horse temporarily (2.257-259), but both become extricable through treachery: Ariadne's and Sinon's (he too is a Greek master of artful deceit-2.195). Each structure was built to deceive and then to kill, and each bewilders its beholders $(2.39,5.589)$ before destroying them. ${ }^{10}$ Confusion before a labyrinthine dilemma, and the question of how best to tackle that situation, will be a recurrent motif in the Aeneid, and its history starts here, as Aeneas begins his narration.

Confronted by the baffling and deceptive work of labyrinthine art, the Trojans hesitate, filled with doubt (2.39). In contrast, the hasty Laocoon charges forward, denounces the horse as a weapon, a hiding place for Greeks, or some other trick (error), and hurls his spear at its curved side. He sees the significance of the dangerous horse almost as clearly as Daedalus understood the maze, and his intended solution to the mystery is nothing if not direct. But while Laocoon's mind penetrates the horse, his spear does not: straightforward approaches and brute force may kill minotaurs, but they don't work with mazes. Had Theseus plunged into the labyrinth unprepared, death would have been certain, and almost throughout the poem, whenever Aeneas tries a direct route, he is forced into circuity. Laocoon's instincts are right: if Troy is to survive, the horse must be destroyed. But just as the Greeks have deceptively constructed their labyrinthine horse, so fate and the gods have shaped a labyrinthine trap for the Trojans; in the cosmic scheme of things, Troy must fall or Rome cannot be founded. Caught in the larger labyrinth crafted by the gods (a subject to which we will return), Laocoon cannot succeed.

The immediate instrument of Laocoon's downfall, and indirectly of Troy's-the twin serpents-also has something in common with mazes.

10. Like the labyrinth (cf. 6.29), the horse is ambiguous, eliciting competing interpretations among the Trojans. Moreover, the description of the wooden horse may hold an aural echo of labyrinthine ambages. Frederick Ahl argues that to read classical writers as they read each other, we must be alert to puns and "included" words-collocations of letters in one or more adjacent words that spell out, or sound very much like, other words - see Metaformations: Soundplay and Wordplay in Ovid and Other Classical Poets (Ithaca: Cornell University Press, 1985). If Ahl is right, one might hear hints of "ambagibus" in compagibus (2.51). 
With their vast coils (2.204), their sinuosity (2.208), their entanglements (2.215), their reduplicated windings (2.218), their knots (2.220), the snakes are as circuitous as the maze and, while not individually biformis, taken together they are as double as the Minotaur itself. When these monstrous beasts glide in from Tenedos, Laocoon is in the midst of sacrificing a bull, and the imperfect tense of the verb mactabat (2.202) is significant: while Laocoon has an accurate interpretation of the horse, his attempt to destroy it is futile, imperfect, incomplete, and similarly he can slay neither the bull nor the quasi-minotaurs within the horse. Instead, he himself is like a wounded bull half-sacrificed (2.223-224) as he falls victim to the mazy snakes. ${ }^{11}$ Oddly enough, it is fitting that in his death throes Laocoon resembles the Minotaur as well as the bull he was trying to sacrifice: Laocoon must die if Troy is to be penetrated by the clever Greeks and Rome established. In this poem, Laocoon is unintentionally on the wrong side; trying to play Theseus's role and save his people, from the only perspective that finally counts he is the bull-man who must die.

Thus the narrative of Aeneas's errores requested by Dido (1.755-756) begins with two disguised manifestations of the labyrinth, though we may well see them as such only in retrospect: the deadly horse as a static parallel to the deceitful house of Daedalus and the serpents as a kinetic mirror of its fatal, convoluted duality, with Laocoon the tragic bridge between them. The crafty product and circling process normally united in the maze are initially broken into constituent parts, ${ }^{12}$ but they come together when the terrible windings of the serpents open the horse's path to Troy.

Troy itself traditionally has labyrinthine associations: it gave its name to medieval and perhaps to ancient mazes and was, like some mazes, virtually impenetrable. ${ }^{13}$ Ironically, the labyrinthine city is penetrated by labyrinthine trickery, and Aeneas, habitual treader of mazes, is driven from the labyrinth of Troy into labyrinthine errores thanks to the sinister manifestations of the maze in horse and serpents. Here we see that it is

11. My association of the Trojan Horse and the serpents with the labyrinth myth is obliquely supported in Dante's Inferno 12, where the Minotaur, conceived in a "false cow" (12.13), plunges back and forth in a simile generally assumed to be derived from Aeneid 2.223-224 (Inf 12.22-24). Apparently, the combined ideas of the wooden cow and the Minotaur brought Laocoon's death to Dante's (subconscious?) mind.

For the Sophoclean tradition that Laocoon deserved to die for impiety, see Joseph Gibaldi and Richard A. LaFleur, "Vanni Fucci and Laocoon: Servius as Possible Intermediary between Vergil and Dante," Traditio, 32 (1976), 386-397.

12. The structure of the first episode in Book 2 -Trojan Horse, Laocoon, the treacherous Sinon, Laocoon's death, the Trojan Horse-constitutes a concentric panel, one common method of achieving what I would call a labyrinthine poetic structure. See Di Cesare, Altar and City, p. 4 o.

13. Cf. the Tragliatella wine-pitcher, chap. 1 above and plate 2 , and the names for turfmazes in chap. 5 . 
not only men who create labyrinths, but also nature and the gods: the human craft of the horse is supplemented by the terrible, divinely ordained serpents. The association of labyrinths with warfare, to be developed in the Trojan Ride and the battles in Italy, begins here, and perhaps too the idea that passion creates mazes, if there is a veiled parallel between the artfully built wooden cow (in which Pasiphae satisfied her lust and begot the monster that occasioned the maze) and the maze-like, minotaurish Trojan Horse, terrible consequence of the forbidden love of another magna regina, Helen, and Paris.

After Troy's walls are breached, Aeneas undergoes labor, error, and other labyrinthine experiences in the mazy city. He ignores Hector's injunction to wander over the seas-to seek foreign errores, as it wereand instead rushes about the city in blind fury, searching a path to the center (2.359-36o) and undertaking untold labores (2.362). There is a covert allusion to the Cretan myth, and perhaps an implication that the tragic cycle of the labyrinth myth is destined for repetition, when Aeneas kills the Greek Androgeos, namesake of Minos's son whose death caused the Athenian tribute to the Minotaur. ${ }^{14}$ As Aeneas follows the path of Fortune rather than common sense (2.387-388), his error (2.412) in donning Greek arms leads to the death of many Trojans. He penetrates the labyrinthine house of Priam with its secret doors and fifty chambers, and his mother Venus promises an end to his labores, granting him a momentary privileged view above the labyrinth of Troy by revealing the gods themselves in combat. Leading his family to safety, he and his comrades seek one goal by many paths (2.716) as in a multicursal labyrinth; they almost achieve it (2.730-731), but Anchises alarms Aeneas, who runs confusedly through unknown byways (2.736), losing Creusa but reaching safety-escaping the maze of Troy, as it were. Immediately he retraces his steps into chaos (2.750-754) until Creusa's ghost sends him forth to Hesperia and a royal wife. Thus Aeneas's path within Troy recapitulates the labyrinth and sets up the expectation that he may continue to run through one maze after another, just as he has done here, throughout the poem. Significantly, he wanders despite supernatural guidance from Hector and Venus and, once, because of Anchises' words, which precipitate dangerous but ultimately profitable deviation as they will do in Books 3 (the journey to Crete), 5 (the founding of Acesta), and 6 (the journey through Hades).

Book 2, then, contains repeated manifestations of the labyrinth and links them with blindness, furor, deceit, violence, and inextricability: escape one maze and you find yourself in another. Moreover, one tragic theme common to the myth and the Aeneid is established: mazes and minotaurs batten on innocent victims. As Athens lost her youths to the

14. Also noted by Boyle, "The Meaning of the Aeneid: II," 116. 
Cretan terrors, so Troy is lost to the labyrinthine horse, so Laocoon and his sons succumb to the sinuous embrace of the serpents, so Creusa is lost in the frantic byways of the city. Even those who triumph over the maze-Daedalus, Theseus, Aeneas in Book 6-suffer losses: Daedalus loses his son, Theseus his father (Aegeus) and son (Hippolytus; cf. 7.1000), and Aeneas a father exhausted by errores and the son-like Pallas, if not Ascanius.

In contrast to Troy, Carthage initially seems to be a counterimage to the maze: a place of rest from errores, a haven of stability, order, and constructive labores. It is a new city nearly completed, with a wellornamented temple and a kindly people at fruitful work. Yet elaborate artful cities are intrinsically, if neutrally, labyrinthine, and thanks to divine trickery, Carthage functions like a maze in malo by imposing delay on Aeneas's fated labor, even if the diversion seems attractive. 15 Carthage shares some of the dangerous doubleness of mazes: as Venus fears, it is for Aeneas a doubtful house (domus ambigua) with inhabitants who, if not biformes, are at least bilingues, double-tongued (1.661). There divine craft and Aeneas's graces transform the noble Dido into a type of Pasiphae, blindly craving an impossible love as she wanders furiously through a newly disordered city. There too Aeneas, glorious as Apollo (or Theseus?) at the labyrinth-dance on Delos (4.143-146), wanders pathless wilds (invia lustra,: $4.15^{1}$ ) before consummating the affair with Dido in a convenient cave. Dido's love turns the orderly splendor of Carthage to chaos with the perverse convertibility of mazes; wherever Aeneas does not find ready-made labyrinths, confusing and apparently inextricable situations are created for him, and at Carthage it takes forceful guidance from Mercury to pry him loose. Dido is abandoned like Ariadne, a casualty of what, to medieval eyes at least, would look like a labyrinth of love.

Thus Books 1-4 subtly, indeed almost imperceptibly, lay the groundwork for the explicit labyrinths of Books 5 and 6 . Aeneas escapes to Italy, like Daedalus, and like him Aeneas unerringly holds the middle course (5.1-2), only to be plunged into a storm as dark, disorienting, and deviation-provoking as a labyrinth. Palinurus retraces the path to Sicily; detour to and delay in Carthage give way to detour to and delay in Sicily. But this is repetition with a difference: the unwitting bringer of disorder in Carthage, Aeneas now imposes order on grief and offers rest after labor when he institutes Anchises' funeral games. Sanctioned by an auspicious seven-coiled serpent (5.85), these games begin and end with implicitly and explicitly labyrinthine rituals: the ship race and the Trojan Ride. ${ }^{16}$

15. Correspondingly, Aeneas's presence delays the completion of the city: all work ceases with Dido's mad love $(4.86-89)$.

16. Images and events from Book 2 recur in varied form: the labyrinthine Trojan Horse is transformed into a labyrinthine Trojan horse-ballet; the malignant serpents bringing 
Like a benevolent maze-maker who will not overtax the players of his game, Aeneas lays out the long course and sets up a visible goal, a signum sequendi to show where the ships must retrace their paths; would that Fate's labyrinths for Aeneas were so clearly demarcated. As in the Cretan myth, lots are drawn, but this sea-voyage is far less risky than the Athenian victims' journey to Crete. Named for monsters, three of them hybrids like the Minotaur (Chimaera, Centaur, Scylla), the ships set forth in noisy confusion. ${ }^{17}$ The twists and turns of the race, the diverse choices of course, the obstacles and collisions, the forced delays, Gyas's casting overboard of his guiding helmsman-all these suggest not merely a safer version of the Trojans' sea-errores but also movement within a multicursal maze. Cloanthus, steering with care the closest course, wins and is fitly rewarded with a cloak bordered by a double meander, a kind of maze, 18 whose center alludes to Daedalus's flight from the labyrinth by depicting Ganymede's eagle-flight to the heavens $(5.250-257)$. This first contest, then, is a well- and fairly structured labyrinth-game, with Aeneas its careful architect.

The funeral celebrations end with another labyrinth game, the lusus Troiae, discussed in Chapter $1 .{ }^{19}$ Here too the dangers of the maze are tamed, and indeed Romanized, as errores define the artistic pattern within which labores joyously imitate the works of war and peace-making which constitute Rome's art. In context, the ritual serves many thematic functions. A counterimage to the Trojan Horse, that violent quasi-maze of war where beast conceals man, the Trojan Ride in equally tricky art shows noble boys in mimic war controlling both beasts and deceptive pattern. Optimistically, it shows Ascanius's symbolic mastery both of the passionate furor that undid Dido, whose horse he rides, and of the labyrinth, thereby pointing to a glorious future for Ascanius himself and for Rome.20 As Pseudo-Bernard Silvester aptly notes, the horse ballet betokens prudence, which "discerns what should be followed and what

death become the benevolent serpent at the funeral games; if Troy was a city destroyed by fire, in Sicily the burning of the ships leads to the building of a new city, but both burnings cause Aeneas great conf usion and doubt. These intricate symmetries reflect a labyrinthine aesthetic.

17. Again following Ahl's methodology, I note the (fairly common) collocation "elabitur undis" (5.151) - a hidden mention of "labyrinthus"? Cf. Knox (in Commager, Virgil), pp. 123-130, for similar sound patterns and their connection with serpents.

18. See chap. 2, n. 3 above.

19. Useful discussions of Book 5 include Di Cesare, Altar and City, pp. $83-85$; Fitzgerald, "Aeneas, Daedalus, and the Labyrinth," 59-61; J. William Hunt, Forms of Glory: Structure and Sense in Virgil's Aeneid (Carbondale: Southern Illinois University Press, 1973), p. 25; Otis, Virgil, pp. 272-276; and, above all, Putnam, Poetry of the Aeneid, chap. 2.

2o. Ascanius's discipline here contrasts with Icarus's tragic indiscipline and heralds Ascanius's self-control in withdrawing from combat in Book 9 after slaying only one rather despicable character. 
should be fled" and ably reads the inherently baffling signa sequendi.21 The happy mood of the well-choreographed ritual recalls the thankful labyrinth dance on Delos celebrating escape from the Cretan maze-a dance that is mentioned fleetingly in Carthage. More pessimistically, however, one might suspect that although triumphs over the maze are possible in controlled conditions, in daily life the guiding signa are not so legible; Ascanius, like Aeneas, may find that the patterns of real war cannot be discerned, let alone diagrammed or committed to memory. Similarly, Aeneas contrives orderly war-games framed by harmless labyrinths in Sicily, but the wars in Italy will be framed by far more fatal and chaotic mazes. ${ }^{22}$ One might remember, too, that just such boys as these Trojan riders fell victim to the Cretan maze, as Polites fell in the sack of Troy, as Lausus and Pallas will fall in Italy. Youth does not always triumph. With characteristic labyrinthine duality, then, the lusus Troiae looks both ways. The delicately traced thousand paths of this playlabyrinth will be retraced triumphantly when the grown Ascanius founds Alba Longa, but in Sicily they coincide temporally and imagistically with Iris's path through the thousand-colored rainbow to incite the burning of the ships $(5.590,609)$, a serious impediment to the Trojans' attaining their true goal and eternal city. If Ascanius masters the labyrinth and its checks, the wavering (ambiguae, 5.655) Trojan women shun further labores $(5.617)$ and ref use to complete their passage. Even Aeneas is caught in a bivium, unable to choose whether to proceed or linger, his indecision in marked contrast to the youths' sure paces. Nautes, master of art and signa sequendi (cf. 5.705), and the ghost of Anchises become double guides to this new maze of uncertainty and counsel a double course: let the weary stay, and let the others proceed to Italy. The solution is in the spirit of the Trojan Ride: incorporate all valid paths into one grand pattern. Yet Aeneas's marking of the boundaries of the new Sicilian city stands in laborious contrast to the gaiety of the boys' ride and the future lusus Troiae at Alba Longa. More sophisticated in his creative response to mazy doubleness, Aeneas advances: after losing Palinurus to that bough of Lethe, an ironic anticipation of the golden bough that leads Aeneas to his helmsman's shade, Aeneas steers his own course past the Sirens to Italy.

The importance of explicit and implicit mazes in Book 6, the "Janusbook," has long been recognized; as the poem's major turning point, this

21. S\&M, p. 28; J\& J, p. 26.

22. As the double meander frames the elevation of Ganymede on Cloanthus's cloak in the ship-race, so the two labyrinth-games frame a kind of elevation of Ascanius in the funeral games section, another instance of labyrinthine structure at work. Later Ascanius is as it were lifted out of the earthly fray by a god when Apollo orders him to stay away from battle $\left(9.63^{8-656)}\right.$. 
book is fitly introduced by Daedalus's maze, whose very presence at this juncture supports a labyrinthine reading of the work. ${ }^{23}$ Mazes hold myriad turning points, however, and the labyrinths of Cumae do not signify that Aeneas, like Ganymede on the cloak and Daedalus in Crete, is about to fly free from errores. On the contrary, Aeneas's first steps in Italy, like his wanderings in Book 3 , lead him through a series of mazes, confirming that arrival in the promised land does not mean an end to labors, errors, or labyrinths. I have discussed the temple sculptures in Chapter 1 , showing that the bright face of the labyrinth displayed in the Trojan Ride here turns dark, exposing violent death, monstrosity, insane lust, and inextricable imprisonment; the ephemeral mastery of Book 5 becomes the partially failed artistry of Book $6 .{ }^{24}$ As the Trojan Ride looks forward to Rome and back to Troy, so too the mazes of Book 6 recapitulate Aeneas's Trojan and Carthaginian past and anticipate the labyrinths of Latium.

Seeking his future path as bidden by Helenus and Anchises, Aeneas comes to the Temple of Apollo at Cumae and confronts the first maze of Book 6, Daedalus's sculpted doors with their legend of the Cretan labyrinth. A would-be Theseus striving to guide his people through seemingly inextricable errores and to found a true home with his labors, Aeneas sees a dubious and ironic image of his struggle: hic labor ille domus et inextricabilis error (6.27), a phrase that effectively paraphrases the whole poem. There, too, are the causes of the inescapable man-made maze: the god-induced passion of a love-mad queen for a bull and their monstrous hybrid progeny. There he sees the sacrifice of innocents and its cause: Minos's vengeance for the death of a beloved son, bringing other youths to unspeakable destruction. And there, perhaps, lies hope: Daedalus, cunning crafter of ambages, unwinding his construction with a thread for

23. Wendell Clausen, "An Interpretation of the Aeneid," Harvard Studies in Classical Philology, $5^{8}$ (1964), 139-147, repr. in Commager, Virgil, pp. 75-88, here, p. 85. Others noting the pivotal nature of this book include Otis, p. 218; Boyle, "The Meaning of the Aeneid: II," 11 ; duBois, History, p. 40.

24. On failed artistry, see Boyle, "The Meaning of the Aeneid, II."

In interpreting the labyrinth in Book 6, many critics compare Aeneas to Daedalus or Theseus and Dido to Ariadne, seeing the doors as cautionary or exemplary art in which Aeneas might read his past to leave it behind (e.g., Zarker) or learn from it (e.g., Fitzgerald). Others view the Cumaean doors as an emblem of secrecy (Knight), protection (Cruttwell), or the kingdom of death in which Aeneas undergoes initiation-rebirth (Knight, Otis, Enk, Di Cesare, Clark). Approaching Book 6 by a different path, I retread some of the same ground as these critics, but with a different perspective.

The most thoughtful treatments of labyrinths in Book 6 are by duBois and Fitzgerald, whose readings and emphases differ from yet are complementary to my own. Enk's short article gives a good overview of previous scholarship. A perceptive reading of Book 6 that omits any explicit discussion of labyrinths but has a good deal to say about Daedalus and failure is Charles Paul Segal's "Aeternum per saecula nomen, the Golden Bough and the Tragedy of History: Part I," Arion, 4 (1965), 61 1 -657, and "Part II," Arion, 5 (1966), 34-72. 
a great queen—but is she Pasiphae or Ariadne?25 —and, implicitly, freed by flight.

What Aeneas finds, though we cannot tell whether he understands it, is indeed his past, present, and future ${ }^{26}$ He has passed through many labyrinths, but many lie ahead: the price of his Italian domus will be continuing, which is to say inextricable, labor and error. Dido's fatal godinduced passion lies behind him; like Theseus, he has cruelly abandoned a generous hostess. Behind him, too, is the wrongful love of Paris and Helen, partial cause of the Trojan War and hence of the humanly crafted and divinely ordained labyrinths of Book 3; but the mad passions of Queen Amata and Turnus await to weave other mazes. Hybrid or double monsters lie behind-in Troy, in the book of errores - and ahead: the snake-haired Allecto, the Dira, and, as we shall see, Turnus and Aeneas himself. So too with the death of (comparative) innocents calling for revenge: Laocoon and his sons, Priam's son Polites, Creusa, Dido, Palinurus, all lie behind, and, ahead, Pallas, Lausus, Camilla. Aeneas's guiding hope is the thread of ambiguous prophecies of Roman destiny, promising that he will transcend the labyrinth and found a new Troy just as Daedalus reduplicated his Cretan domus by artistry in a foreign land. As this reading of past and future history latent in the doors indicates, however, the labyrinthine prognosis is not optimistic. Theseus's escape from the labyrinth was followed by an ill-fated descent to Hades, from which he had to be rescued by Hercules, and Daedalus himself flew from the labyrinth because he could not escape its toils any other way. The cost of escape-the loss of Icarus-was so great that it made him leave his sculpture unfinished, endless as labyrinths and errores seem to be while one is in them. Similarly, Aeneas's escapes from his mazes may not be permanent, and if he is to be architect of his new domus after so many failed attempts, he too, or so the doors suggest, will pay a heavy price. Aeneas is trapped in labyrinthine delays as he peruses the sculpture until the guiding Sibyl rudely extricates him: he is not to muse on mazes but to tread them. ${ }^{27}$

The second labyrinthine structure in Book 6 is the Sibyl's noisy cave with its hundred doors-or so anyone familiar with descriptions of the Egyptian labyrinth might think. Modern archaeology has confirmed what Virgil, who wrote the Aeneid nearby, presumably knew well: the

25. On the ambiguity of "magnum reginae... amorem," see Fitzgerald, "Aeneas, Daedalus, and the Labyrinth," 63n14.

26. On Aeneas's silence and incomprehension, see Fitzgerald, duBois, and Segal. DuBois takes the Cumaean relief as a kind of psycho-history, representing Aeneas's present.

27. Aeneas's first task is to sacrifice seven bullocks and ewes whose number recalls the youthful Athenians in the relief: Iuvencus (6.38), significantly, can mean either bullock or young man. Fitzgerald notes the connection between Aeneas's sacrifice and the tribute to the Minotaur ( p. 58) but interprets Aeneas's act as payment for the Sibyl's prophecies. I would see the allusion as a suggestion that the mythic pattern is beginning yet again. 
Sibyl's cave lies at the end of a long man-made tunnel with lateral galleries and rooms branching off, and finally three rooms of which the last is further subdivided in three. The place itself, like Virgil's description, is thus quite labyrinthine. ${ }^{28}$ Here Aeneas invokes Apollo, patron of errant islands, ambiguous oracles, and labyrinthine gates, as former guide through the seas of Book 3 and reminds him of the Trojans' labores and wandering gods (errantes, 6.68); here the Sibyl, in ambages common to maze (6.29) and oracle (6.99) alike, foretells future trials recapitulating the wars of Troy but promises a safe path (6.96). Like the temple doors, these prophecies entangle truth with uncertainty (obscuris vera involvens, $6.100)$, and the Sibyl's proffered guidance is hardly as palpable as Ariadne's thread. Nor is this the help Aeneas wants: instead, he craves to follow Theseus and Hercules to Hades (6.122-123), a passage the Sibyl describes as intensely arduous: "easy is the descent to Avernus: night and day the door of gloomy Dis stands open; but to recall thy steps and pass out to the upper air, this is the task, this is the toil! [hoc opus, hic labor est]." ${ }^{29}$ In this second labyrinth of Book 6, then, Aeneas finds ambiguous guidance, wishes to emulate the maze-solver Theseus, and hears the annunciation of yet another maze-or, rather, two, for the quest for the golden bough itself involves Aeneas in something very like a maze, at least by the standards of early Christian writers. ${ }^{30}$

If Virgil's Hades is most labyrinthine in its fabled inextricability, it

28. See Raymond V. Schoder, "Vergil's Poetic Use of the Cumae Area," CJ, 67 (197172), 97-105, and extensive notes and diagrams in R. G. Austin's edition of and commentary on Book 6 (Oxford: Clarendon Press, 1977). Borgeaud reports that excavations at Ephyre, where Theseus descended into the Underworld, reveal a temple of Hades designed as a labyrinth: see "The Open Entrance," p. 19.

29. Fairclough's trans. The resemblance to the earlier description of the labyrinth is noted by Verrall, Enk, and Fitzgerald, among others. Petrarch apparently assumed that Virgil's Hades was a labyrinth: 'I knew that the 'descent to Avernus was easy,' the gate of the labyrinth was wide, and that the way out was hard and difficult to find" (Liber sine nomine: $\mathrm{Z}_{11} \mathrm{1}_{\mathrm{D}} \mathrm{D}_{2} 18$ ). In the Corbaccio (p. 10), Boccaccio also alludes to Virgil as he descends into the labyrinth of love.

3o. Cf. Ambrose and Gregory Thaumaturgus, chap. 3. The goal-the bough-is hidden in a vast, thick wood and imprisoned by shadows; to find it, Aeneas must rely on two doves sent by Venus, who point the way (6.194) and offer signs (6.198) to follow. (PseudoBernard Silvester also emphasizes the wood's impenetrability and tracklessness-S\&M, p. $6 o ; \mathrm{J} \& \mathrm{~J}$, p. 62). These elements loosely evoke a labyrinth, especially if one harks back to Aeneas's path to the Cumaean temple, which juxtaposes Trivia's grove with the golden temple of Apollo (Triviae lucos atque aurea tecta, 6.13). As the path to Daedalus' sculptures involves trees and gold, so too does the path to the labyrinth of Hades. Lines 9-263 involve concentric panel-or labyrinthine-structure: see Quinn, Virgil's Aeneid, pp. 16o-161.

The golden bough itself was associated with a bivium, if not with a full-fledged labyrinth, by commentators: see Servius, ad 6.136, on the Pythagorean Y, followed by PseudoBernard Silvester (S\&M, p. 63; J\&J, p. 64) and Landino (see Jane Chance, "The Medieval Sources of Cristof oro Landino's Allegorization of the Judgment of Paris," SP, 81 [ 1984], 145-160). After a précis of Pseudo-Bernard's reading of the Aeneid, John of Salisbury compares correct moral judgment to the discovery of a straight path in the midst of tangled error, for which one needs the bough of virtue as guide: Policraticus 8:24-25.

See also Segal, "Aeternum per saecula nomen: Part I" on the bough's ambiguities. 
nevertheless shares other characteristics with the maze. To the living it is normally impenetrable: only with talisman and guide can Aeneas fathom its secrets and acquire the knowledge he seeks. Entered through a cave, the vast domus Ditis (6.269) is dark and cavernous, filled with hybrid monsters: centaurs, scyllae biformes (2.286), gorgons, harpies, the hundred-headed Briareus, the Hydra, Geryon, Cerberus $(6.285-289$, 417421 ). Peopled by errant shades (6.329), Hades has serpentine rivers, the nine-fold inextricable inremeabilis Styx $(6.425,439)$, and various paths, including a bivium (6.540) whose right-hand path leads to Elysium, its left-hand path to Tartarus and the castle of Cretan Rhadamanthus, where Theseus is perpetually imprisoned. Among its denizens Hades numbers other Cretans: Minos as a judge, with his urn (and the proximity of infants and the falsely executed) recalling the drawing of lots for his slaughter of innocent Athenians in Crete; Phaedra; Pasiphae (6.426436 ; 445; 447).

On the paradoxically easy path (6.776) of the Elysian Fields, Aeneas finds Anchises, who praises his son's mastery of the hard journey, the iter durum, through piety (6.698). There Aeneas sees, without full understanding, his own posterity, the city-builders and law-givers, bringers of stability. Yet stability is finally impermanent: even in Elysium one has no certain home (6.672), and while the cycles of metempsychosis render Hades extricable to some, they also prescribe a potentially endless sequence of earthly labors, a concept that naturally horrifies Aeneas $(6.719-721){ }^{31}$ One is freed from the Underworld only to face the labores and errores of life again, imprisoned in yet another blind prison, the body (6.734). Error and labor are endless, and the vision of Roman glory is barely adequate compensation. No wonder Aeneas, arriving in the new world, seeks a straight path (6.90o) to Caieta.

Aeneas may have escaped Hades, and he may have bade farewell to his Trojan and Carthaginian past, as many critics believe, ${ }^{32}$ but he has hardly escaped from labyrinths, for Books 7-12 continue to lead him in winding paths. ${ }^{33} \mathrm{He}$ first passes daedala Circe's isle; like Pasiphae a daughter of the sun, Circe too creates hybrid monsters, men in bestial shapes and perverse Daedalian breedings (7.282); she weaves fine webs in her impenetrable grove, and her very name conjures up the circles of the maze. ${ }^{34}$ Yet her dangers are only metaphorically meant for Aeneas;

31. Cf. Augustine's horror of the cycles of pagan time, discussed in chap. 3 .

32. E.g., Boyle, "The Meaning of the Aeneid: I"; L. A. MacKay, "Three Levels of Meaning in Aeneid 6," Transactions and Proceedings of the American Philological Association, 86 (1955), 180-189; Otis, Virgil, p. 303; Rutledge, "The Opening of Aeneid 6," 112.

33. This would not have surprised Fulgentius, who etymologized Lavinia's name as "laborum via": Fulgentius the Mythographer, trans. Leslie George Whitbread (Columbus: Ohio State University Press, 1971), p. 108.

34. Most Roman pavement labyrinths were square, but the Cretan form of the maze (see plates 1, 2), well-known across the Mediterranean, was circular. 
his labors and labyrinths now will have to do with war-war created simply as one further delay by Juno, angry that the Trojans have found a path through all obstacles $(7.296-315)$. Her agents, predictably, are another hybrid (Allecto with her serpent hair and vicious wandering [7.557]) and another distraught queen, Amata, herself invaded by, indeed fused with, a serpent of wrath recalling those of Book 2 (7.346$353) \cdot{ }^{35}$

In this chaos of war, Aeneas finds allies and divine weapons, which in turn evoke the idea of the labyrinth. Aeneas arrives at Pallantium during the festival of Hercules, that man of labors who also escaped twin serpents and returned from hell. His local adventure with Cacus, described at length $\left(8.185^{-270}\right)$, reveals parallels to Theseus's triumph in Crete and anticipates Aeneas's combat with Turnus. ${ }^{36}$ Vile inhabitant of an impenetrable cave whose doors were decked with the heads of his murdered human fodder, ${ }^{37}$ Cacus stole Geryon's bulls from Hercules, dragging them backward into his cave: "and, with the signs of their course thus turned backwards, he hid them in the rocky darkness; whoso sought them could find no marks leading to the cave" (8.209-212; trans. Fairclough). The lines connote a labyrinth, a dark and inaccessible house, grave of innocent victims, with the deceptive signa sequendi found in mazes. Here this monster-semihomo, semifera $(8.194,267)$, like the Minotaur-was finally destroyed by Hercules, liberator of cattle and of the tribes from whom Cacus had exacted such fearful tribute. Hercules is a model for Aeneas: savior of peoples, master of labores imposed by Juno's wrath, flouter of inextricability, destroyer of blind evil. ${ }^{38}$ Yet Hercules, dressed in a lion's skin and given to fury, liberator of beasts as well as men, is also a warning: do not become the monster you destroy, do not let Theseus merge with the Minotaur.

Another optimistic image similarly undercut is Aeneas's shield, product of the Daedalian art and labor of Vulcan-Cacus's father as well as Venus's husband. Woven in sevenfold circles (8.448), miraculously textum (8.625), its pageants of Roman history intertwined with dolphins leaping through the sea (cf. the Trojan Ride, 5.594-595), the shield is at once a work of complex art heralding the end of Aeneas's labors and a harbinger of war and violence. Its first vignette, the roots of Rome, depicts

35. Note that errare is used to describe the serpent's movements. Extending the labyrinthine parallels, Amata spins in circles (7.379) and leads her matrons in pathless woods $(7.580)$.

36. Anderson, Art of the Aeneid, pp. 71-72, also discusses parallels between the HerculesCacus and Turnus-Aeneas battles.

37. Cf. the victims depicted on the doors at Cumae, Turnus's displaying the heads of Nisus and Euryalus outside the Trojan fort in Book 9, and his decorating his chariot with the heads of Trojan brothers (12.511-512), incidents that link Turnus with Cacus.

38. Putnam, Poetry of the Aeneid, p. 134, notes puns on kakós (Greek: evil) and caecus (blind) in Cacus's name. 
the twins Romulus and Remus suckled by the wolf - another unnatural conjunction of beast and man, and an instance of doubleness that, with Romulus's murder of Remus, will become duplicity. Cities are founded on death. This is part of the burden of fame that Aeneas, rerum ignarus, lifts on his shoulders.

In Books 9-12 the labyrinths of war, faintly adumbrated by the Trojan Horse and Ride and the shield, ambiguously enunciated in the labyrinths of Cumae and Hades, become manifest. Book 9 recapitulates Book 5: the bewildered Turnus and his horsemen besiege the Trojan camp, wildly circling its impenetrable walls and finding no entrance (9.57-58); their movements recall the labyrinthine mock-battle of the Trojan Ride, but while the Trojan boys imposed order on chaos, now, with labyrinthine convertibility, chaos reigns alone. As in Book 5, incendiary Iris urges the destruction of the Trojan fleet, but again there is repetition with a difference: Virgil develops the second mazy simile from the Trojan Ride as the ships are miraculously changed into seanymphs who frolic like dolphins (9.119-120), eventually warning Aeneas of his people's peril. ${ }^{39}$

Imprisoned in their virtually impenetrable and inextricable camp and greedy for fame, Nisus and Euryalus decide to find a dangerous path through the encircling foe to summon Aeneas to the rescue. Sure of the bivium they seek and of their path through the dark valleys $(9.238,243-$ 245), believing, as it were, that they know the labyrinthine ground through which they must pass, they possess the confidence of the youths in the Trojan Ride and the blessing of Ascanius. ${ }^{40}$ Yet the riders' mastery of the maze in Sicily, their ability to turn war to peace, finds no match in the youthful pair's Italian exploits. The path they seek becomes a broad road of mayhem (9.323) as Nisus slaughters sleeping Rutulians like a lion in a sheepfold (9.339), cutting a path instead of following one (9.356). Instead of delivering their message, they become minotaurs, beast-men, and thus it is fitting that they never escape the maze alive. As tisey follow the left bend of the road (9.372), a glint of moonlight on Euryalus's plundered helmet betrays them to approaching reinforcements, who

39. The dolphin motif is also noted by Cruttwell, Virgil's Mind, pp. 93-96; Di Cesare, Altar and City, p. 84; and Putnam, Poetry of the Aeneid, p. 87.

4o. Are the seven gif ts Ascanius offers them (9.263-266) a talisman related to the traditional seven circles of the Cretan maze in its ancient representations? Does Mnestheus's gift to Nisus of a lion's skin (9.306-307) simultaneously recall Hercules' rages and foreshadow the leonine rampage on which the Trojans embark? The contrasts between this expedition and the games on Sicily may be pointed by the reference to the game one of the Trojans' victims had recently finished playing and would no doubt have liked to prolong $\left(9 \cdot 337-33^{8}\right)$. So too Nisus and Euryalus, runners in that deceptive footrace on Sicily, might have wished their graver exploits in Italy had a happier outcome, as they might have done had the pair kept their original noble goal in view. 
block off all escape: "On this side and that the horsemen bar the wellknown crossways, and with sentinels girdle every outlet. The forest spread wide with shaggy thickets and dark ilex; dense briars filled it on every side; here and there glimmered the path through the hidden glades" (9.379-383; trans. Fairclough). Euryalus's ill-gotten booty hinders him (impediunt: 9.385 ; cf. $5.585,593$ ) and he mistakes his path, only to be taken; it is as if his furor and greed have transformed a theoretically penetrable forest into an inextricable labyrinth. Nisus gets free but turns back to find his friend: "Where shall I follow, again unthreading all the tangled path of the treacherous wood [rursus perplexum iter omne revolvens fallacis silvae]? Therewith he scans and retraces his footsteps and wanders [errat] in the silent thickets" (9.390-393; trans. Fairclough). The lexis of labyrinths is as dense as the forest itself, and one is reminded of Aeneas's fruitless quest for Creusa in the maze of fallen Troy. Finally both youths die in redeeming nobility, but their errand into the treacherous maze has brought failure and death. The Trojan Ride has small counterpart in real war, and the Trojan pair's overconfidence and failure find a parallel later in Book 9 in Turnus's failure to end the war when, having penetrated the Trojan camp, his blood-lust leads him to insane slaughter like a tiger among the herds when the simple expedient of opening the gates to his army $\left(9.730,75^{6-761)}\right.$ would have ruined the Trojans. He manages to escape, doubtfully retracing his steps (9.797) to withdraw from this particular prison as Nisus and Aeneas earlier retraced their steps into war-mazes, but Turnus too will shortly find himself in another labyrinth.

Book 10 offers no significant labyrinths, though it reminds us of the high price demanded by mazes and war alike: the wasteful deaths of noble youths like Pallas and Lausus. In Book 11 , however, Turnus once again seeks out a labyrinthine setting for the slaughter of Trojans and once again fails, in this case by retracing his steps too soon. Hearing that Aeneas is approaching through the mountains while his cavalry attacks in the plains, Turnus leaves the main battle to Camilla and sets an ambush in a winding valley suitable for tricks (doli) of war. There is a dark, narrow, vaulted path through impenetrable woods; the entrance is narrow, and the path can be blocked by Rutulian troops in a double pass (biviae fauces, suggesting perhaps the fatal throat of the double Minotaur). Above is a secret plain from which reinforcements can charge downward to the right or left or hurl stones at the foe $\left(11.5^{1} 5^{-5} 5^{16,522-}\right.$ 529). This description of the constrained, covered path through the impassable forest and the double jaws of the gorge evokes the Cretan labyrinth, whereas the mountain hiding-place and the possibility of hurtling stones at victims echo the description of Cacus's cave. Turnus, like the Minotaur and Cacus, has the advantage of knowing the territory 
(regione viarum, 1 1.530), and here surely he would have prevailed had he not left prematurely after hearing of Camilla's death in another labyrinthine combat. ${ }^{41}$

But the labyrinth of war cannot be evaded for long. In the midst of general battle, Turnus and Aeneas begin a final if intermittent engagement whose pattern is strikingly labyrinthine. Frantic to save her brother Turnus, the goddess Juturna assumes the form of his charioteer and steers Turnus erratically across the battlefield, this way and that, as Aeneas tracks him in winding circles $(12.481-482)$. Frustrated by their failure to meet face to face, Aeneas and Turnus rage and slaughter indiscriminately until Aeneas attacks the Latin city, Amata kills herself, and Turnus finally seeks single combat. Aeneas and Turnus battle like bulls (12.716): both, maddened in warfare, have become like minotaurs. Turnus races insanely along labyrinthine paths, now here, now there, entangling doubtful circles (incertos implicat orbis, 12.743) and finding himself in an inextricable situation, surrounded by Trojans, a vast marsh, and high walls (12.744-745). His steps impeded (impediunt, 12.747), Aeneas pursues like a hound after a stag who, terrified of high banks and traps, flees and turns again on a thousand paths (mille fugit refugitque vias, 12.753; cf. 5.590, the labyrinth's paths also being banked by walls). This is the true labyrinth of war, earnest of the Trojan Ride's game, as "five circles they weave at a run and retrace [retexunt] as many again, this way and that; they seek no light nor playf ul [ludicra] prize, but strive for Turnus' blood and life [12.763-764]." Jupiter sends down a fierce hybrid, a Dira-perhaps Allecto, who first caused the wars in Book 7-and Virgil stresses her double nature by describing her as one of a pair of serpent-haired winged twins (12.845; there are traditionally three Dirae). As if to signal that the mad race through the maze is over and it is now time to face the Minotaur, Aeneas decries delay and flight; using the language of the labyrinth myth, he challenges Turnus to use art, to fly to the stars, or to hide in a cave (12.892-893) if he must escape. Trapped like Cacus, ambushed as he had hoped to ambush Aeneas, Turnus responds like Cacus or as he himself had planned in the mountain pass: he hurls a stone, but one that fails of its mark. In an action echoing Laocoon's attack on the Trojan Horse, Aeneas casts his spear through the outermost circle of Turnus' seven-circled shield (12.925):

41. If Turnus plots an ambush reminiscent of mazes and of Cacus's fight with Hercules, Camilla's exploits suggest the labyrinth and Euryalus's fatal flaw in his labyrinthine journey. Camilla kills Orsilochus by a circular flight in which she doubles back in a narrower circle to cut him off (11.694-695), and she dies by the spear of the crafty Arruns, who repeatedly circles and tracks her, trying now this approach, now that, until, her true goal displaced by the desire for booty, she opens herself to his attack $(11.759-817)$. Her death is described in words exactly echoed-or retraced?-in Turnus's death $\left(11.831,12.95^{2}\right)$. Ironically, Turnus's labyrinthine ambush is cut short just moments before success $\left(\begin{array}{ll}11.903-905) \\ )\end{array}\right.$ the labyrinthine strategies of Aeneas' most unattractive ally, Arruns. 
this time the protective labyrinth is breached, and Turnus wounded. Though Turnus begs for mercy, Aeneas sees the (in)signum (12.944) that must be followed to escape this labyrinth of war: the baldric plundered from Pallas, which enrages Aeneas enough to kill Turnus. At the chronological beginning of Aeneas's history within the Aeneid, Laocoon died like a bull after trying to penetrate the labyrinthine Trojan Horse with brute force; at the end, raging like a bull, Aeneas succeeds because he has already caref ully trodden all the mazes laid down by the gods, and in the heart of the labyrinth, action that seems shockingly direct after so much circuitousness is the only appropriate response. Yet the Aeneid closes not with Aeneas, but with Turnus' descent to the shadows of another labyrinth, Hades. A minotaur has been killed, but the labyrinth, and perhaps a hero who partakes of minotaurish rage, survives. ${ }^{42}$

Framed chronologically by labyrinths of war (the horse, the single combat of Turnus and Aeneas) and enclosing labyrinths of art (the Trojan Ride, the Daedalian panels) at its center, the Aeneid and its iter durum unfold as a sequence of labyrinths: explicit and implicit, architectural and narrative, labor as art, labor as toil, error as wandering, error as misjudgment. The mythical labyrinth characters are all there: Minos, lawgiver and vengeful destroyer of innocents; Pasiphae and Phaedra, afflicted by the gods with insane passion; Androgeos, beloved son whose death begets further tragedy; the Minotaur, terrifying beast-man of cruel appetite; Daedalus, cunning architect both master of and mastered by his complex art; Icarus and Hippolytus, youths cut down in their first flowering; Ariadne, the gracious guide abandoned; Theseus, ambiguous savior and seducer, treader of labyrinths in Crete, Delos, and Hades. All of them appear not merely as themselves but in others-Dido, Turnus, Cacus, Pallas, Ascanius, Lausus, and most particularly Aeneas himself. The myth provides an implicit commentary on the poem, hinting at a dark continuity of human motive and pattern. Qualities associated with the labyrinth appear and reappear, often in conjunction: darkness; inextricability; interwoven circular errores, circuitous processes, unforeseen delays, sudden checks, forced or voluntary retracings of steps; paths of ignorance, physical ambages, and verbal ambiguities; crucial choices guided by equivocal signa sequendi (omens, dreams, prophecies); passive endurance of a path imposed by unseen forces. The concept of the city as labyrinth appears in Books 2 and 4 and figures in the allusion to the Trojan Ride at Ascanius's foundation of Alba Longa, lending irony to

42. Even critics whose readings of the poem do not seriously involve the idea of the labyrinth recognize at some level that the poem ends in a maze: cf. Hunt, who describes "a labyrinthine maze of dream and reality interf used and of success and failure inextricably mingled" (p. 86), and Adam Parry, "The Two Voices of Virgil's Aeneid," Arion, 2, 4 (1963), 66-8o, repr. in Commager, Virgil, pp. 107-123: "Aeneas' end . . . will see him as far from his fulfillment as his beginning" (p. 118). 
Aeneas's quest for a stable city, a fixed domus Aeneae: will Rome too exhibit not merely the artistic order but also the chaos of the double labyrinth? Is the poem a series of labyrinthine journeys in search of new labyrinths? The ancient linkage of fame and labyrinths figures in the Aeneid as well: the Trojan Ride commemorates Anchises and, for the reader, anticipates the future fame of Rome, elsewhere depicted in the labyrinths of Hades and Aeneas's shield. Since ancient mazes in Egypt and Etruria were monuments to the dead, does the covert association of fame with labyrinths here celebrate chiefly the dead-including the victims of the road to Rome? As Pliny challenged the vast (and largely wasted) expense of the ancient monuments, does Virgil hint that the costs of building Rome may also be disproportionately great? ${ }^{43}$ The labyrinth's endlessness appears in a particularly frustrating form: solving one maze brings brief triumph, but another maze always lurks.

In style and structure, the Aeneid employs a labyrinthine aesthetic (see Chapter 7). Lexically and syntactically, its style of ten relies on ambiguity. ${ }^{44}$ The poem mimics the infinitely intricate and highly patterned design of the maze in many ways. Aeneas's geographical wanderings trace a pictorial labyrinth of error; moreover, the Aeneid is the locus classicus of what medieval rhetoricians called artificial order-an order associated with the maze in Chapter 7.45 Beginning in media res, the poem constantly winds backward and forward in time, not only in narrative chronology but also in the patterns of retold histories, prophecies, and fulfillments. As in a maze, the same ground is retraced time and again, literally and metaphorically, and while there is undoubtedly linear progress, cyclical patterns also emerge. As we have seen, the blending of linear and cyclical movement finds a visual analogue in the circular labyrinth. ${ }^{46}$ Moreover, the poem is highly artificial and labyrinthine in its symmetries, particularly in its use of ring structure, concentric panels (in which the narrative leads to a central point and then retraces its steps outward), and interlace. ${ }^{47}$ Diagrams of the poem-and admittedly there

43. On Virgil's doubts about the adequacy of fame as compensation, see Hunt, Forms of Glory, esp. pp. 35-36; Boyle, "The Meaning of the Aeneid: II," 133-135; and Segal, "Aeternum per saecula nomen," parts 1 and 2.

44. See Camps, Introduction, p. 64, and Quinn, Virgil's Aeneid, pp. 127 and 394-414.

45. The best-known medieval discussion of the Aeneid in this context is Pseudo-Bernard Silvester's, which comments on the poem's double point of view and double narrative order, noting that frequent ambiguities demand multiple interpretation: S\&M, pp. 3-5 and $11 ; \mathrm{J} \& \mathrm{~J}$, pp. $1-3$ and 9 .

46. Thus I disagree with duBois's statement that Virgil "cannot trust absolutely any meta-historical patterning of history, either cyclical or linear" (History, pp. 49-50); I believe Virgil conflates and af firms both traditional views of history by adopting the model of the maze.

47. For descriptions of the poem's elaborate symmetrical structure, see Otis, Virgil, chaps. 6 and 7 and p. 392; Quinn, Virgil's Aeneid, chap. 3; Camps, Introduction, chap. 6 and passim; George E. Duckworth, Structural Patterns and Proportions in Vergil's Aeneid: A Study of 
could be almost as many as there are analysts-thus suggest the concentric symmetry of the maze. Structure repeatedly calls attention to itself, and Virgil's art imposes an intensely complex artistic order on the of ten chaotic events related, so that the reader is far more closely attuned to parallels and symmetries than the characters trapped within the history being related.

There may be many reasons for Virgil's preoccupation with structure. Complicated narrative patterns were fashionable, as Catullus's Carmen 64 (significantly, also concerned with the labyrinth myth) demonstrates; obviously Hellenistic and Augustan poets prided themselves on Daedalian linguistic architecture. W. A. Camps rightly suggests that Virgil imposes architectural unity where Aristotelian unity is lacking-and I would add that the particular architectural model evoked is the labyrinth. 48 Perhaps, like some Ricardian poets, Virgil favored ornately patterned structure as a metaphorical defense against and response to the confusions and uncertainties of his world. ${ }^{49}$ But whatever its causes, the Aeneid's labyrinthine structure has important and somewhat paradoxical effects: on one hand, it supports the assumption that just as the poem is more tightly and carefully structured than the world it describes seems to be, so too there is a complex, elegant, symmetrical (and therefore rational) cosmic order wrought by a divine craftsman that we can only take on faith. On the other hand, the Aeneid shows the failure of Daedalus and the irrationality and limited control of the gods; in that context, perhaps the only truly rational order is that imposed by an artist or poet who creates labyrinths of symmetry where reality off ers only labyrinths of chaos.

I am arguing, then, that Virgil made such extensive use of the idea of the labyrinth in the Aeneid that it becomes one of what Michael Putnam calls the "unifying imaginative patterns discernible in any masterpiece." 50 The labyrinth might have seemed appropriate for many reasons. Its myth provided an archetypal narrative for the story to be told-

Mathematical Composition (Ann Arbor: University of Michigan Press, 1962), chaps. 1 and 2; Philip Holt, "Aeneid V: Past and Future," CJ,75 (1979), 110-12 1; Hunt, Forms of Glory; and Gordon Williams, Technique and Ideas in the Aeneid (New Haven: Yale University Press, 1983), pp. $75^{-81}$.

48. Cf. Camps, Introduction, pp. 58-59. Virgil generally liked concentric panel construction (see Otis, Virgil, passim) and reduplicated narrative patterns within a work (see A. M. Crabbe, "Georgic 4 and the Aeneid," Proceedings of the Virgil Society, 17 [1978-80], 10-31).

49. Cf. Charles Muscatine, Poetry and Crisis in the Age of Chaucer (Notre Dame: University of Notre Dame Press, 1972), chap. 2, "The Pearl Poet: Style as Defense."

5o. Putnam, Poetry of the Aeneid, p. x. I hesitate to claim the maze as the central image because the labyrinth myth does not obviously account for recurrent images of fire and the hunt. On these images, see Boyle, "The Meaning of the Aeneid: I," 81-85; Knox, "The Serpent and the Flame"; Hunt, Forms of Glory, chap. 6; Otis, Virgil, pp. 70-79, 240-250; and Putnam, Poetry of the Aeneid, chap. 4, esp. pp. 171-172 on "tracking" and p. 187 on impious fury. 
a dangerous, self-sacrificial, circuitous quest through uncertainty and confusion to destroy evil and establish a new and stable order, but an order whose stability can never be taken for granted, as the histories of Theseus, Aeneas, and Rome suggest. Its architectural significance as order containing chaos provided a model for poetry and the Roman art of government alike, and also a warning that the costs of order may be high and order itself unstable and dependent upon one's perspective. It was also an appropriate vehicle for examining and tying together a number of major philosophical concerns. Let us close by looking at how the labyrinth works in this regard.

What is the nature and order of the world in which Aeneas struggled? It is, of course, a labyrinth. To wanderers within its darkness, especially those without supernatural guidance, it consists of delay, detours, confusion, apparent futility. As Gordon Williams writes, "Only the backward view inspires confidence; there is no view forward." 51 Without the overview that external guidance or historical hindsight can provide, there is only chaos. Even with guidance, even for Aeneas, who is occasionally granted privileged vision-the vision that can found an empire-the possibilities of reliable knowledge remain scant. Supernatural guidance of ten takes the form of dim and ambiguous prophecies, like Apollo's oracle in Book 3. Omens must be interpreted: the Trojans misread the twin serpents from Tenedos, and only Anchises understands what the flame on Ascanius's head signifies (2.680-704). Dreams and visions may offer clear advice, as when Hector's ghost urges Aeneas to flee Troy (2.289-295), but advice may not be followed. Without supernatural intervention, Aeneas could never accomplish his labors; with it, his path is far from clear or easy. If the hero, with privileged vision, finds the labyrinth hard to fathom, how much harder is it for those who can't see far enough, or from a high enough vantage point? Even when Aeneas views the future in Hades or on his shield, he cannot fully grasp what he sees and remains profoundly rerum ignarus. Although there are multiple internal perspectives on the action of the Aeneid, no perspective-not even Jupiter's - seems fully reliable. ${ }^{52}$ Thus the labyrinth, with its emphasis

51. Williams, Technique and Ideas, p. 39.

52. On the function of visions and supernatural intervention, see N. C. Webb, "Direct Contact between the Hero and the Supernatural in the Aeneid," Proceedings of the Virgil Society, 17 (1978-80), 39-49.

On Virgil's use of multiple perspective, see Gian Biagio Conte, The Rhetoric of Imitation: Genre and Poetic Memory in Virgil and Other Latin Poets, trans. Charles Segal (Ithaca: Cornell University Press, 1986), pp. 157-179, and Philip Holt, "Aeneid V," and "Who Understands Vergil's Prophecies?" CJ, 77 (1982), 303-314. Otis, Virgil, chap. 3, considers the tensions between Virgil's "subjective style" and his alleged desire to "expound a single moral and point of view which will dominate the reader."

On problems with Jupiter's knowledge, see Quinn, "Did Virgil Fail?" in Cicero and Virgil: Studies in Honor of Harold Hunt, ed. John R. C. Montago (Amsterdam: A. M. Hakkert, 1972), repr. in Harold Bloom, Modern Critical Views: Virgil (New York: Chelsea House, 
on the importance of perspective, is an appropriate model for the kind of world in which perfect knowledge (and therefore perfect action) is impossible, even to gods.

Labyrinths have architects, at least in theory. Who is the architect of Virgil's labyrinth-world? The gods modify the mazes Aeneas must tread: Juno designs delays and diversions, and Jupiter intercedes, through Mercury, to get Aeneas back on track. Jupiter, who views the world from above as if it were a map (1.223-226), can unroll the scroll of fate (1.262); but who wrote it? Since disorder is as prevalent among gods as among men and even Jupiter's efficacy is not unquestionable, we can conclude only that there is no absolute and omnipotent architect, or at least none whom Virgil lets us see. ${ }^{53}$ Virgil himself is inside a labyrinth, seeing clearly only in retrospect.

Labyrinths simultaneously address and evade the question of free will vs. determinism in that all mazes limit the range of possible choices, and unicursal labyrinths preclude all choice (other than whether or not to continue) after entry. ${ }^{54}$ Free will is therefore operative but restricted, very much as in the Aeneid. Clearly Aeneas and his descendents will found and rule Rome: the goal of the labyrinth is prescribed by fate and confirmed by history. Yet that goal can be reached in a number of ways, some defined by the gods (e.g., the diversion to Carthage), some by human choice (e.g., whether to kill Turnus). There are, it seems, at least three levels of path-mapping and maze-defining: Fate's, the gods', and humanity's. Fate disposes broadly, the gods alter details, and men choose among fixed options. Although Aeneas protests "I do not pursue Italy of my own free will" (4.361), of ten he does move voluntarily. Thus a complex labyrinth, unicursal in some places and multicursal in others, with adjustable walls that can be moved arbitrarily to create and remove dead ends, constitutes an excellent model for how fate and free will operate in the Aeneid. Once one enters, the ultimate goal is established, but unicursal stretches between moments of significant choice (e.g., the storms in which Aeneas and his people have no control of direction) require persistence, and multicursal junctures demand choice. Internal flexibility may reduce or increase the time required to complete the course, and

1986), pp. 73-83, which suggests that some discrepancies result from Virgil's incomplete revision of the poem.

53. Cf. Gordon Williams, Technique and Ideas, p. $3^{8}$, for whom the gods are "a synecdoche for the chaos and lack of pattern that characterize events viewed in the immediate context of their occurrence."

54. See chap. 2. For conflicting discussions of free will and determinism in the Aeneid, see, e.g., Conte, Rhetoric of Imitation, pp. 175-179; Otis, Virgil, pp. 353-354, 377, and passim; Camps, Introduction, chaps. 4-5; Williams, Technique and Ideas, chaps. 1-2; Quinn, Virgil's Aeneid, p. 123; Parry, "Two Voices," 118 and 123; and W. R. Johnson, Darkness Visible: A Study of Vergil's Aeneid (Berkeley: University of California Press, 1976), pp. 114134 . 
may lead down this path or another. Because the master-maze thus contains a series of successive labyrinths, the question of what to follow, what to flee, is crucial $(3.459-460,6.892)$. Yet the signa sequendi are confused, deceptive, conducive to error (5.590-591). The Aeneid argues that, however independent and wise one may be, the cards are stacked. For most of us, the labyrinth wins in the end, especially when architects and gods unfairly change the course and the rules in mid-journey, as they of ten do (see particularly the divine interventions in Book 12).

Because the maze offers some choice, there are better and worse ways to tread it. Pietas, the paramount virtue in the Aeneid, is a quality most necessary in mazes, where success involves persistence in and respect for the paths and goals that are laid out, patient endurance of the unavoidable twistings and confusions that lie between bivia, and the exercise of moral intelligence at points of choice. If Aeneas is not perfect in this respect, he does a better job of maze-walking than anyone else (with the possible exception of the comparatively untried Ascanius who, having mastered the labyrinth in play, opts out of the labyrinth of war at Apollo's injunction). Turnus fails in the labyrinth because he, like his divine allies, cannot accept its existence and constraints; a brave and of ten sympathetic antagonist, he denies the order imposed by prophecy and human agreement and tries to step out of established paths altogether until finally he is trapped in a maze of death.

Yet Aeneas too fails to achieve perfect virtue, and taking the labyrinth as a model for the world of the Aeneid explains his failure. First, no one can see well enough to tread the labyrinth perfectly: as error is inherent in the maze's structure, so it is in the choices made within, especially when guidance is ambiguous. Yet even if perfect vision were possible, it might not be enough. As labyrinths are characteristically dual and convertible, so are those trapped within, at least in Virgil's view. What Theseus battles in the maze is the Minotaur, the man-beast, and in the successive labyrinths of the Aeneid the monster within can never be slain once and for all. All humanity is double, hybrid; all are potentially minotaurs. ${ }^{55}$ This theme of doubleness, of hybridization, echoes throughout the poem. There are hybrid creatures: the harpies, the beasts on Circe's island, the terrors at the elm of false dreams in Hades, Allecto, the beasts conquered by Hercules (including Cacus, half-man, halfbeast), the Dira who brings Turnus to despair. There are men conjoined with animals: the Trojan Horse, the Trojan sailors in their ships named for hybrids, Daedalus and Icarus as bird-men, Pasiphae in her wooden cow, Amata invaded by the serpent, Hercules and Nisus with their lions' skins, Turnus with the chimera on his helmet and the cow-woman Io on

55. Pseudo-Bernard Silvester predictably associates the hybrids in Hades with vice: S\&M, pp. 68-72; J\&J, pp. 70-75. 
his shield, ${ }^{56}$ Romulus and Remus at the wolf's teats. Men fight like beasts in the labyrinth of war: Nisus, Euryalus, Turnus, even Aeneas. Things of ten come in twos, for no particular narrative reason: two serpents in Troy (and twin snakes in Allecto's maddening of Turnus, in Hercules' infant labor, in the depiction of Cleopatra); two doves leading to the (hybrid) golden bough; the double plumes of Romulus seen at Lethe; two gates at the exit to Hades (where one might have expected Aeneas merely to retrace his steps); double gates of war in Latium and in Olympus; the centaur-like twins Catillus and Coras, the pairs of twins or brothers slain in Troy and Italy, the double flame on Augustus's head on Aeneas's shield, the two robes woven by Dido that Aeneas brings forth to place on Pallas's bier (only one of which is actually used). Latinus swears vainly by Latona's twins (Apollo and Diana, patrons of the Cumaean labyrinths) and double Janus that the treaty in Book 12 will not be broken.

This insistent iteration of doubleness and hybridization points to a deeper dualism in the universe and in mankind, ${ }^{57}$ a dualism enhanced by Aeneas' own double ancestry: human and divine, Cretan and Italian (cf. 3.180, where Anchises reveals his "ambiguous race and double ancestry"). Yet this dualism also figures in an optimistic pattern: as Aeneas's double ancestry resolves itself in a single Aeneas, as the two lines of Aeneas and Evander are traced back to a single root (8.142), so the double heritage, Italian and Trojan, will generate one nation (12.19o$191,820-828$ ). All men are double, minotaurs, in some proportion or other, and therefore human failure is inevitable because of what men are as well as because they tread continual labyrinths. Yet unity, or at least a fusion of duality, is fleetingly possible, as we see in one of the noblest images in the poem: the Trojan youths mastering their horses in the labyrinthine complexities of the Trojan Ride. The fragility of unity and order renders them the more admirable and also the more tragic: men tame labyrinths only in ephemeral games.

Virgil's vision is bleak: human history is an unending series of labyrinths inhabited at best by would-be incarnations of Theseus who discover that they themselves may act like minotaurs. Virtuous action is possible, but not continuously. Escape is possible, but it is temporary: one recurrent pattern in the poem is escape, celebration, and entry into another labyrinth. Thus Daedalus escapes from Crete, dedicates his wings to Apollo, and sculpts a maze; Theseus solves the labyrinth, celebrates at Delos with a labyrinth dance, and enters the labyrinth of Hades; Aeneas flees the labyrinths of Troy and the waves, appears in

56. DuBois also notes this point (History, pp. 39-40).

57. Cf. Brooks, "Discolor Aura," 146, who notes "that particular dualism which is the essence of the Aeneid." 
Carthage like Apollo at the Delian dances, and falls into labyrinths of love; he escapes through labyrinthine storms to Sicily and celebrates with the Trojan Ride only to seek out Cumae and the terrible labyrinths of war. We and he see visions of his descendants, of the glory his labors and errors make possible, but he himself is left in the maze, having slain a minotaur but having done so in a fury that leaves him suspect. His reward is deferred, present within the poem only in prophecy. If chaos and order alternate in the Aeneid as in perceptions of the labyrinth, the poem ends with chaos. If one labyrinth is extricable, the succession of labyrinths is endless. The achievement of even temporary order may well be worth while-the labyrinth, after all, is far worse-yet the costs of that inevitably impermanent order are high.

Many readers, particularly those adopting a perspective from within the labyrinth, find in the poem a profound sense of human waste and failure; others, espousing a more detached overview, see the triumph of order and pietas. In the Aeneid as in a labyrinth, both responses are simultaneously and equally valid, and one might argue that because failure is inevitable, because the odds are so long, fleeting success and virtue (which need not coincide) are all the more laudable. ${ }^{58}$ Labyrinths, like life, involve chaos and order, destiny and free choice, terror and triumph-all held in balance, all perspective-dependent. In the Aeneid, that is simply how the universe is built.

Book 1 begins with Virgil's singing of Aeneas's quests for a stable city and ends with another song by the Carthaginian Iopas: "hic canit errantem lunam solisque labores" (1.742). "He tells of the wandering moon and the sun's labors": the creation of man and beast, rain and fire, the guiding Triones, haste and delay. Iopas's song, caref ully balancing one item against another, is a tightly structured labor, a work of art like Virgil's, though in miniature. Iopas condenses and crystallizes the labyrinthine meanings and cycles of the Aeneid: in the beginning were error and labor, the moon and the sun, the twins Diana and Apollo who guard the double Cumaean doors. In the beginning was the cosmic labyrinth. And the results? Man and beast, the elements of the Minotaur. Rain and

58. Thus I would finally disagree with Boyle, who values Turnus more highly than Aeneas simply because Aeneas aims higher and fails to reach that goal; even at his worst, I would argue, Aeneas is more admirable even though imperfect. Putnam too is disappointed in Aeneas: Poetry of the Aeneid, chap. 4, esp. pp. 192-193. See also Douglas J. Stewart, "Aeneas the Politician," Antioch Review, 32, 4 (1973), repr. in Bloom, Modern Critical Views: Virgil, pp. $103^{-118 .}$

Taking more moderate positions on Aeneas's failure are Brooks, Clausen, Johnson (who gives perhaps the most sensitive refutation of Boyle's and Putnam's positions, pp. 1 14-134), Parry, Hunt, Quinn (esp. chap. 1), and George E. Dimock, Jr., "The Mistake of Aeneas," Yale Review, 64 (1975), 334-356. For generally positive views of Aeneas's achievement, see Otis, esp. pp. 313-382; Rutledge, "Opening of Aeneid 6" and "Vergil's Daedalus"; and Anderson, Art of the Aeneid. For an overview of the debate, as well as a discussion of inconsistencies in the poem, see Quinn, "Did Virgil Fail?" pp. 73-83. 
fire, life-giving and life-destroying, elements of Aeneas's sea-journeys and Dido's passion and the Italian wars, elements coming together in the repeated image of the storm. The "gemini Triones," the constellation of the plough-oxen or the greater and lesser bears: ${ }^{59}$ these celestial guides are also beasts, one destructive, the other plodding but productive, the pairing suggesting the minotaur that is man with his double nature. Speed and delay, straightforward passage vs. the circuitousness of the labyrinth. In the world of the poem as in Iopas's song, all these dualities are necessary and inescapable; together they define the cosmic labyrinth within which human history, before and after death, must also be a story of journeys through the maze. As for the art that gives us a privileged view of the labyrinth, we are left with an analogous vision: Daedalus crafting a well-structured but unfinished sculpture that is only partially studied by Aeneas in an elaborately constructed but unfinished, or at least unpolished, poem. ${ }^{60}$

59. Often called the Septemtriones rather than the two triones. Presumably the use of one form would evoke the other, and although Virgil stresses duality in Iopas's song, seven is an important number for the labyrinth, as the common Cretan design had seven circuits. In this context, the seven circles of Aeneas's and Turnus's shields, already noted, connote the labyrinth. Similarly, that Aeneas is inconsistently described as having wandered for seven years both on his arrival in Carthage (1.755) and almost a year later in Sicily (5.626) suggests an intentional association of Aeneas's wanderings with the labyrinth. The sevenfold serpent winding around the altar in Sicily might anticipate the labyrinthine Trojan Ride. One might also see a succession of seven cities leading from Troy to Rome: Aeneadae, Pergamum in Crete, Buthrotum, Carthage, Acesta, Alba Longa, and finally Rome.

6o. See Quinn, "Did Virgil Fail?"; that the Aeneid remained unfinished at Virgil's death was well known to later ages thanks to Donatus's Life. 